\title{
Status Gizi dan Status Perkembangan Balita Usia 12-36 Bulan
}

\author{
Indraswari Siscadarsih ${ }^{1 *}$, Hesty Widyasih ${ }^{2}$ \\ ${ }^{1}$ Sekolah Vokasi Universitas Gadjah Mada \\ ${ }^{2}$ Poltekkes Kemenkes Yogyakarta \\ *Email korespondesi: indraswari@poltekkesjogja.ac.id
}

Article Info

Article history:

Submitted: 2020-05-14

Accepted: 2020-05-19

Published: 2020-05-28

Keywords:

Toddler, nutrition, development

ABSTRACT

Malnutrition can be caused by delays in growth in children, including the development of gross motor, fine motor, language skill, and personality. Nowadays, $43 \%$ of children in developing countries are feared to have developmental disorders, and only $30 \%$ of pre-school children with developmental disorders are identified earlier. This study aimed to determine the relation of nutritional status and developmental status of children aged 12-36 months in Puskesmas Jetis Kota Yogyakarta. The design of this study was cross-sectional. The target population was children aged 12-36 months with 84 samples which are obtained by consecutive sampling. Nutritional status was obtained from measurements of weight and height or length from the WHO Standard. Developmental observations using the Denver II test. The data analysis used is fisher's exact test. The result is the majority of the subject were in good nutrition and in good development status. There was a correlation between nutritional status and the developmental status of children aged 12-36 months with $p$-value 0,001 . Underweight children were more likely 13,8 risk to have suspect development status compared to those in wellnourished.

\section{ABSTRAK}

Kata kunci:

Balita, status gizi, perkembangan
Keadaan gizi buruk maupun gizi kurang mengakibatkan anak mengalami pertumbuhan dan perkembangan terlambat, meliputi perkembangan motorik kasar, motorik halus, bahasa, dan kepribadian. Saat ini, 43\% anak di negara berkembang dikhawatirkan akan mengalami gangguan perkembangan dan hanya $30 \%$ anak pra sekolah dengan gangguan perkembangan yang teridentifikasi sebelumnya. Penelitian ini bertujuan untuk mengetahui hubungan status gizi dengan status perkembangan balita usia 12-36 bulan di wilayah Puskesmas Jetis Kota Yogyakarta. Desain penelitian ini adalah cross sectional. Populasi target adalah seluruh balita usia 1236 bulan dengan jumlah sampel 84 yang diambil dengan consecutive sampling. Status gizi diperoleh dari pengukuran berat badan dan tinggi atau panjang badan yang diolah dengan standar WHO. Observasi perkembangan dilakukan dengan tes Denver II. Analisis data yang digunakan adalah fisher exact test. Hasil penelitian menunjukkan sebagian besar subjek memiliki status gizi dan status perkembangan dalam kategori baik. Terdapat hubungan antara status gizi dengan status perkembangan balita usia 12-36 bulan dengan $p$-value 0,001 . Balita dengan gizi kurang berisiko 13,8 mengalami perkembangan suspect dibanding balita gizi baik. Rekomendasi untuk petugas kesehatan sebaiknya memiliki program yang inovatif untuk mencegah gizi kurang dan perkembangan abnormal. 


\section{PENDAHULUAN}

Badan kesehatan dunia (WHO) memperkirakan 54\% kematian bayi dan anak dilatarbelakangi oleh keadaan gizi yang buruk. Di dunia, sekitar 10\% anak-anak mengalami gizi kurang dengan z-score antara -3 dan $<-2$ yang memiliki risiko kematian tiga kali lebih besar dari anak-anak gizi baik. ${ }^{1}$ Negara-negara berkembang seperti sebagian besar Asia, Afrika, Amerika Tengah dan Amerika Selatan pada umumnya mempunyai masalah gizi kurang. ${ }^{2}$ UNICEF tahun 2011 juga menemukan jutaan anak di Asia Tenggara dan Asia Selatan tidak mendapatkan gizi yang dibutuhkannya.

Data dari WHO tahun 2011 menunjukkan bahwa di Indonesia gizi buruk menyumbangkan angka $80 \%$ penyebab kematian anak. Berdasarkan data Kementerian Kesehatan RI tahun 2017, balita Indonesia memiliki TB/U normal dan BB/TB normal sebanyak $61,1 \%$, sedangkan $38,9 \%$ lainnya masih mengalami masalah gizi. Sejumlah $23,4 \%$ balita berpotensi mengalami kegemukan, 3,4\% gizi buruk, dan $14,4 \%$ gizi kurang. Sementara itu, masalah balita kurus di Indonesia telah memasuki kategori akut dengan 3,1\% balita sangat kurus dan $8,0 \%$ balita kurus. Prevalensi balita pendek juga tinggi, yaitu sebesar $27,5 \%$ (kategori kronis) yang terbagi menjadi balita sangat pendek $8,5 \%$ dan balita pendek $19,0 \% .^{3}$ Data Riskesdas 2018 menunjukan 30,8\% balita di Indonesia masih mengalami stunting. ${ }^{4,5}$

Saat ini, 43\% anak di negara berkembang dikhawatirkan akan mengalami gangguan perkembangan dan hanya $30 \%$ anak pra sekolah dengan gangguan perkembangan yang teridentifikasi sebelumnya.6,7 Masalah ketidakadekuatan stimulasi kognitif, kurang gizi, defisiensi zat besi dan defisiensi iodium menduduki empat peringkat teratas faktor risiko perkembangan anak. ${ }^{8}$ Begitu juga dengan jenis kelamin, usia, jumlah anak dalam keluarga, pernikahan kerabat, tingkat pendidikan orang tua, pendapatan rumah tangga, riwayat menyusui, riwayat persalinan, faktor intrauterin, dan infeksi pada balita juga mempengaruhi perkembangan anak usia dini. ${ }^{7,9}$

Kaitannya dengan gizi, penelitian ini perlu dilakukan pada anak usia 12-36 bulan (batita) karena pada usia 12 bulan anak sudah mengalami maturasi otak dan kesiapan mental untuk bicara. Pada saat inilah merupakan saat yang tepat untuk dilakukan deteksi dini gangguan perkembangan pada anak. ${ }^{10}$ Menurut Desfita tahun 2007 dan UNICEF tahun 2016, anak dibawah 36 bulan berada pada periode kritis pertumbuhan dan perkembangan otak yang cepat. Manifestasi dari gizi kurang pada batita apabila tidak diperbaiki sejak dini dapat menyebabkan penurunan kualitas fisik, mental, dan produktivitas kerja. $6,11,12$ Penelitian ini dilakukan untuk mengetahui hubungan status gizi dengan status perkembangan balita usia 12-36 bulan di wilayah Puskesmas Jetis Kota Yogyakarta.

\section{METODE PENELITIAN}

Desain penelitian ini adalah studi analitik cross sectional untuk melihat hubungan status gizi dengan status perkembangan balita usia 12-36 bulan di wilayah Puskesmas Jetis Kota Yogyakarta pada Bulan September sampai dengan Desember 2017. Populasi terjangkau pada penelitian ini adalah seluruh balita usia 12-36 bulan di wilayah Puskesmas Jetis Kota Yogyakarta sebanyak 189 balita. Besar sampel dalam penelitian ini dihitung menggunakan rumus Lemeshow untuk desain cross sectional estimasi proporsi berjumlah 84 orang. Teknik pengambilan sampel menggunakan consecutive sampling dengan kriteria inklusi yaitu balita didampingi pengasuh utamanya saat pemeriksaan Denver II dan memiliki buku KIA. Kriteria eksklusi dalam penelitian ini yaitu balita sedang menjalani pengobatan atau sedang 
sakit saat penelitian seperti demam, batuk, pilek, diare, TBC, DB, malaria, campak, dan DPT; untestable setelah dilakukan pemeriksaan Denver II dan status gizi lebih setelah dilakukan pengukuran antropometri. Teknik pengumpulan data menggunakan data primer yaitu status gizi balita menurut IMT/U berdasarkan pengukuran antropometri yang mengacu pada baku standar WHO 2005; status perkembangan balita berdasarkan Denver II; karakteristik balita dan orang tua yang diperoleh dari hasil wawancara. Pengolahan data mulai editing, coding, prosessing, cleaning. Analisis univariat dengan distribusi frekuensi dan analisis bivariate dengan fisher's exact test. Uji ini digunakan dalam penelitian untuk menganalisis hubungan dua variabel dengan data ordinal dan nominal karena syarat uji chi square tidak terpenuhi (25,0\% cell memiliki nilai expected kurang dari 5). Penelitian ini telah mendapatkan ethical clearance dari Medical and Health Research Ethics Committee (MHREC) Faculty of Medicine Universitas Gadjah Mada Nomor Ref: KE/FK/1134/EC/2017 tanggal 19 Oktober 2017.

\section{HASIL PENELITIAN}

\section{Analisis Univariat}

Dalam penelitian ini analisis univariat digunakan untuk melihat distribusi status gizi dan status perkembangan balita di Wilayah Puskesmas Jetis Kota Yogyakarta.

Tabel 1. Distribusi Frekuensi Status Gizi dan Perkembangan Balita menurut IMT/U Usia 12-36 Bulan di Wilayah Puskesmas Jetis Kota Yogyakarta

\begin{tabular}{lccc}
\hline Variabel & $\begin{array}{c}\text { Frekuensi } \\
(\mathbf{n})\end{array}$ & $\begin{array}{c}\text { Persentase } \\
(\%)\end{array}$ & $\begin{array}{c}\text { Rerata } \pm \text { SD } \\
(\mathbf{z} \text {-score) }\end{array}$ \\
\hline Status Gizi & & & \\
Kurang & 15 & 17,9 & $-0.31 \pm 1,59$ \\
Baik & 69 & 82,1 & \\
Status Perkembangan & & & \\
$\quad$ Suspect & 16 & 19,0 & \\
$\quad$ Normal & 68 & 81,0 & \\
\hline
\end{tabular}

Sumber: Data Primer, 2017

Berdasarkan Tabel 1 dapat diketahui bahwa persentase balita gizi kurang berdasarkan IMT/U dalam penelitian ini adalah sebesar $17,9 \%$ dan rerata $z$-score 0,31 . Status perkembangan balita dengan perkembangan suspect dalam penelitian ini adalah sebesar $19 \%$.

\section{Analisis Bivariat}

Dalam penelitian ini analisis bivariat digunakan untuk mengetahui hubungan status gizi dan status perkembangan balita dengan fisher's exact test yang tersaji dalam tabel berikut:

Tabel 2. Analisis Bivariat antara Status Gizi dengan Status Perkembangan Balita Usia 12-36 Bulan di Wilayah Puskesmas Jetis Kota Yogyakarta

\begin{tabular}{|c|c|c|c|c|c|c|c|c|c|}
\hline \multirow{3}{*}{ Status gizi } & \multicolumn{4}{|c|}{ Status Perkembangan } & \multirow{3}{*}{$\begin{array}{c}p- \\
\text { value }\end{array}$} & \multirow{3}{*}{ C } & \multirow{3}{*}{ PR } & \multirow{2}{*}{\multicolumn{2}{|c|}{ 95\% C.I. }} \\
\hline & \multicolumn{2}{|c|}{$\begin{array}{c}\text { Suspect } \\
(\mathrm{n}=16)\end{array}$} & \multicolumn{2}{|c|}{$\begin{array}{l}\text { Normal } \\
(n=68)\end{array}$} & & & & & \\
\hline & $\mathrm{n}$ & $\%$ & $n$ & $\%$ & & & & Upper & Lower \\
\hline Kurang & 12 & 80,0 & & 20,0 & 0,001 & 0,586 & 13,8 & 5,2 & 36,9 \\
\hline Normal & 4 & 5,8 & 65 & 94,2 & & & & & \\
\hline
\end{tabular}

Sumber: Data Primer, 2017 
Tabel 2 menunjukkan bahwa terdapat hubungan yang signifikan antara status gizi (IMT/U) dan status perkembangan balita dengan $p$-value 0,001 . Koefisien kontingensi 0,568 menunjukkan adanya korelasi cukup kuat antara status gizi dan status perkembangan balita dengan prevalensi rasio 13,8 pada $95 \%$ Cl 5,2 s.d 36,9 .

\section{PEMBAHASAN}

Berdasarkan Tabel 1 dapat diketahui bahwa persentase balita gizi kurang berdasarkan IMT/U sebesar 17,9\%. Hasil Riskesdas tahun 2013 menunjukkan status gizi buruk nasional tahun 2013 sebesar 5,3\% dan gizi kurang sebesar 6,8\%. Berdasarkan uraian tersebut dapat disimpulkan bahwa temuan gizi kurang dalam penelitian ini memiliki persentase yang lebih tinggi dibanding angka nasional. ${ }^{13}$

Gizi kurang juga ditemukan pada penelitian yang dilakukan oleh Sudfeld tahun 2015 di Tanzania, bahwa dari 1036 balita usia 12-36 bulan, terdapat 9,0\% diantaranya mengalami gizi kurang dengan rata-rata z-score -0,67. Apabila dibandingkan, rerata $z$-score dalam penelitian ini lebih tinggi yaitu sebesar $-0,31 .{ }^{14}$ Sementara itu, penelitian Chang tahun 2012 yang melibatkan 1967 balita usia 6-59 bulan di bagian selatan Malawi menyebutkan 16,9\% responden mengalami gizi buruk kronis setelah dilakukan pemantauan selama 12 bulan. Status gizi pada penelitian Chang diukur menggunakan indikator BB/TB-PB, sedangkan pada penelitian ini status gizi diukur menggunakan indikator IMT/U sehingga hasil lebih spesifik karena melihat aspek umur, cara pengukuran, BB, dan TB/PB dalam waktu yang bersamaan. ${ }^{15}$ Penelitian lain yang dilakukan oleh Skau tahun 2015 yang diikuti selama sembilan bulan menunjukkan sebanyak $11,3 \%$ dari 419 balita usia $6-15$ bulan di Cambodia mengalami gizi kurang dengan indikator berat badan berdasakan umur. ${ }^{16}$

Berdasarkan Tabel 1 dapat diketahui bahwa persentase balita dengan status perkembangan suspect dalam penelitian ini adalah $19 \%$. Sementara $43 \%$ anak di negara berkembang dikhawatirkan akan mengalami gangguan perkembangan dan hanya $30 \%$ anak pra sekolah dengan gangguan perkembangan yang teridentifikasi sebelumnya. ${ }^{6,7}$ Beberapa penelitian cross sectional yang dilakukan di Vietnam, Indonesia, Nepal, dan Zanzibar, serta longitudinal intervention trials yang dilakukan di Itali, Spanyol, dan Honduras juga menunjukkan masih adanya perkembangan terhambat pada balita. ${ }^{17}$

Penelitian ini dilakukan pada balita usia 12-36 bulan karena masa kanakkanak merupakan masa kritis terhadap perkembangan sehingga diperlukan rangsangan atau stimulasi yang berguna agar potensi yang ada bisa berkembang. Anak usia 12 bulan sudah mengalami maturasi otak dan kesiapan mental untuk bicara. Pada saat inilah merupakan saat yang tepat untuk dilakukan deteksi dini gangguan perkembangan pada anak. ${ }^{10}$ Masa kanak-kanak juga sangat kritis terhadap perkembangan kognitif, motorik, dan sosio-emosional, namun derajat pertumbuhan fisik, perkembangan anak, dan faktor penentu dari masalah tersebut masih sulit diketahui. ${ }^{14}$ Pada masa batita (1-3 tahun) pertumbuhan anak relatif lebih lambat dibandingkan dengan masa bayi, akan tetapi perkembangan motoriknya berjalan lebih cepat. ${ }^{18}$

Berdasarkan hasil fisher's exact test antara status gizi dan status perkembangan balita dengan $p$-value sebesar 0,001 yang menunjukkan adanya hubungan signifikan antara kedua variabel tersebut. Persentase balita gizi kurang yang memiliki status perkembangan suspect adalah sebesar $83,3 \%$, sedangkan balita dengan gizi baik yang mengalami perkembangan suspect adalah sebesar $1,5 \%$. Hasil koefisien kontingensi menunjukkan hasil 0,586 yang berarti terdapat 
korelasi cukup kuat antara status gizi dengan status perkembangan balita $(0,40<C$ $<0,60 \mathrm{Cmax}$ ). Prevalensi rasio 13,8 pada $95 \% \mathrm{Cl}$ antara 5,2 s/d 36,9 menunjukkan bahwa dalam populasi yang diwakili oleh subyek penelitian, kita percaya $95 \%$ rasio prevalensinya terletak antara 5,2 sampai dengan 36,9. Nilai PR $>1$ dan $\mathrm{Cl}$ tidak mencakup angka 1 menunjukkan variabel tersebut (gizi kurang) merupakan faktor risiko terjadinya efek (perkembangan suspect). Penelitian ini berarti bahwa balita gizi kurang memiliki risiko 13,8 kali lebih besar untuk mengalami perkembangan suspect dibandingkan dengan balita gizi baik.

Anak-anak yang berstatus gizi kurang mengalami hambatan perkembangan yang terjadi karena penurunan jumlah dan ukuran sel otak. ${ }^{19}$ Paparan awal gizi buruk dan infeksi akan menyebabkan gangguan pertumbuhan dan perkembangan yang simultan karena terjadi pemangkasan neuron di daerah otak yang berpengaruh pada tugas motor, memori belajar dan kognitif. Infeksi kronis maupun kurang gizi dapat menghambat kemajuan keterampilan motorik awal yang berpengaruh pada keterlambatan kognitif. Hal tersebut juga dapat terjadi karena berkurangnya kemampuan anak untuk mengeksplorasi dan kurangnya kesempatan belajar atau menggali hal baru dari lingkugan fisik dan sosial. Gangguan pertumbuhan dan gizi kurang juga dapat menjadi penyebab keterlambatan perkembangan secara lebih luas dan berpengaruh langsung terhadap kognitif dan perkembangan motorik. ${ }^{14}$

Pertumbuhan dan kemampuan sistem saraf pada otak untuk membuat dan melepaskan neurotransmitter tergantung pada konsentrasi zat gizi tertentu dalam darah yang diperoleh dari komposisi makanan yang dikonsumsi, sehingga kekurangan gizi pada anak akan menyebabkan anak lemah, tidak aktif, dan gangguan fungsi perhatian yang mengakibatkan retardasi pertumbuhan dan perkembangan anak sebagai tanda ketidakseimbangan antara jumlah asupan gizi dengan kebutuhan penggunaan zat gizi oleh tubuh terutama otak. ${ }^{20-22}$ Menurut LaGrone, et al tahun 2012, anak-anak dengan gizi kurang juga akan memiliki risiko yang lebih besar terhadap penyakit menular, penurunan tinggi badan saat dewasa, dan penurunan produktivitas. ${ }^{1}$

Penelitian ini sesuai dengan meta analisis yang dilakukan oleh Sudfeld tahun 2015 di Tanzania tentang adanya hubungan antara status gizi dengan perkembangan kognitif, sosioemosional, dan motorik balita. Hasil penelitian tersebut menguatkan dasar penemuan besar tentang hubungan kurang gizi kronis dengan perkembangan kognitif dan defisit perkembangan motorik. Sudfeld juga berpendapat bahwa peningkatan gizi akan memperbaiki kemampuan sosial, perilaku, dan peningkatan kognitif. Defisit kognitif di awal kehidupan harus mendapat intervensi segera karena dapat bertahan sepanjang masa. ${ }^{14}$ Penelitian lain juga menyebutkan adanya hubungan antara status gizi dengan perkembangan motorik kasar, yaitu penelitian pada 240 balita usia $5-18$ bulan di Vietnam. ${ }^{17}$ Jahari tahun 2000 mengatakan bahwa makanan atau nutrisi akan meningkatkan energi yang akan berkontribusi terhadap perkembangan balita terutama sektor motorik. ${ }^{23}$ Studi lain dengan fisher's exact test yang dilakukan Kasenda tahun 2015 dan regresi logistik yang dilakukan Hizni tahun 2010 juga menunjukkan bahwa status gizi berhubungan dengan perkembangan bahasa, motorik kasar, dan motorik halus balita. ${ }^{11,22}$ Penelitian di Vietnam tahun 2005 yang dilakukan oleh Watanabe menyimpulkan bahwa anak dengan gizi buruk pada usia dua tahun pertama kehidupan akan memiliki status perkembangan terhambat saat usia 8 dan 11 tahun. ${ }^{24}$ 


\section{SIMPULAN DAN SARAN}

Terdapat hubungan antara status gizi dan status perkembangan balita usia 12-36 bulan di wilayah Puskesmas Jetis Kota Yogyakarta. Saran bagi bidan, petugas gizi, psikolog, dan Kepala Puskesmas Jetis Kota Yogyakarta yaitu perlunya melakukan tindak lanjut terhadap balita gizi kurang dan balita perkembangan suspect untuk meminimalkan dampak dari kejadian tersebut, serta peningkatan kinerja dan inovasi program preventif pencegahan gizi kurang dan perkembangan abnormal seperti pemantauan gizi dan stimulasi perkembangan.

\section{DAFTAR PUSTAKA}

1. LaGrone LN, Trehan I, Meuli GJ, Wang RJ, Thakwalakwa C, Maleta K, et al. A Novel Fortified Blended Flour, Corn-Soy Blend 'Plus-Plus,' is Not Inferior to Lipid-Based Ready-to-Use Supplementary Foods for the Treatment of Moderate Acute Malnutrition in Malawian Children. Am J Clin Nutr [Internet]. 2012 Jan 1;95(1):212-9. Available from: https://academic.oup.com/ajcn/article/95/1/212/4576583

2. Gella N, Lerik MDC, Limbu R. Analisis Perbedaan Perkembangan Antara Anak Balita Gizi Baik Dengan Balita Gizi Kurang Studi Di Kelurahan Karang Siri Kota Soe Tahun 2012. J Media Kesehat Masy [Internet]. 2013 [cited 2020 May 19];VII(2). Available from: https://id.scribd.com/document/328917982/Analisis-Perbedaan-PerkembanganAntara-Anak-Balita-Gizi-Baik-Dengan-Balita-Gizi-Kurang-Studi-Di-Kelurahan-KarangSiri-Kota-Soe-Tahun-2012

3. Kementerian Kesehatan R.I. Buku Saku Pemantauan Status Gizi Tahun 2016. Jakarta: Kementerian Kesehatan R.I.; 2017.

4. Kementerian Kesehatan R.I. Laporan Riset Kesehatan Dasar Tahun 2018. Jakarta: Kementerian Kesehatan R.I.; 2019.

5. Kadar Ramadhan. Status Gizi menurut Tinggi Badan per Umur pada Balita. Poltekita J IImu Kesehat [Internet]. 2019 Apr 27;13(2):96-101. Available from: http://jurnal.poltekkespalu.ac.id/index.php/JIK/article/view/38

6. Lake A. Investing in Early Childhood Development Essential to Helping More Children and Communities Thrive, New Lancet Series Finds [Internet]. unicef.org. 2016 [cited 2020 May 19]. Available from: https://www.unicef.org/press-releases/investing-earlychildhood-development-essential-helping-more-children-and

7. Çelikkiran S, Bozkurt H, Coskun M. Denver Developmental Test Findings and their Relationship with Sociodemographic Variables in a Large Community Sample of 0-4Year-Old Children. Noro Psikiyatr Ars [Internet]. 2015 Jun 11;52(2):180-4. Available from: http://www.noropsikiyatriarsivi.com/crossref?doi=10.5152/npa.2015.7230

8. Walker SP, Wachs TD, Meeks Gardner J, Lozoff B, Wasserman GA, Pollitt E, et al. Child Development: Risk Factors for Adverse Outcomes in Developing Countries. Lancet [Internet]. 2007 Jan;369(9556):145-57. Available from: https://linkinghub.elsevier.com/retrieve/pii/S0140673607600762

9. Daelmans B, Black MM, Lombardi J, Lucas J, Richter L, Silver K, et al. Effective Interventions and Strategies for Improving Early Child Development. BMJ [Internet]. 2015 Sep 14; h4029. Available from: http://www.bmj.com/lookup/doi/10.1136/bmj.h4029

10. Soetjiningsih, Ranuh IN. Tumbuh Kembang Anak. 2nd ed. Jakarta: EGC; 2015.

11. Hizni A, Julia M, Gamayanti IL. Status Stunted dan Hubungannya dengan Perkembangan Anak Balita di Wilayah Pesisir Pantai Utara Kecamatan Lemahwungkuk Kota Cirebon. J Gizi Klin Indones [Internet]. 2010 Mar 1;6(3):131. Available from: https://jurnal.ugm.ac.id/jgki/article/view/17721

12. Desfita S, Sudargo T, Adiyanti MG. Hubungan Status Gizi dengan Perkembangan Mental dan Psikomotor Anak Usia 12 Sampai 24 Bulan di Daerah Endemis GAKI. J Gizi Klin Indones [Internet]. 2007 Mar 1;3(3):122. Available from: https://jurnal.ugm.ac.id/jgki/article/view/17563 
13. Kementerian Kesehatan R.I. Laporan Riset Kesehatan Dasar Tahun 2013. Jakarta: Kementerian Kesehatan R.I.; 2014.

14. Sudfeld CR, Charles McCoy D, Danaei G, Fink G, Ezzati M, Andrews KG, et al. Linear Growth and Child Development in Low- and Middle-Income Countries: A MetaAnalysis. Pediatrics [Internet]. 2015 May 1;135(5):e1266-75. Available from: http://pediatrics.aappublications.org/cgi/doi/10.1542/peds.2014-3111

15. Chang CY, Trehan I, Wang RJ, Thakwalakwa C, Maleta K, Deitchler M, et al. Children Successfully Treated for Moderate Acute Malnutrition Remain at Risk for Malnutrition and Death in the Subsequent Year after Recovery. J Nutr [Internet]. 2013 Feb $1 ; 143(2): 215-20$. Available https://academic.oup.com/jn/article/143/2/215/4569841

16. Skau JK, Touch B, Chhoun C, Chea M, Unni US, Makurat J, et al. Effects of Animal Source Food and Micronutrient fortification in Complementary Food Products on Body Composition, iron Status, and Linear Growth: a Randomized Trial in Cambodia. Am J Clin Nutr [Internet]. 2015 Apr 1;101(4):742-51. Available from: https://academic.oup.com/ajcn/article/101/4/742/4564489

17. Kulkarni S, Ramakrishnan U, Dearden KA, Marsh DR, Thu Ha T, Duc Tran T, et al. Greater Length-for-Age Increases the Odds ff Attaining Motor Milestones in Vietnamese Children Aged 5-18 Months. Vol. 21, Asia Pac J Clin Nutr. 2012.

18. Nursalam. Konsep dan Penerapan Metodologi Penelitian IImu Keperawatan Pedoman Skripsi, Tesis, dan Instrumen Penelitian Keperawatan. 2nd ed. Jakarta: Salemba Medika; 2008.

19. Ati CA, Alfiyanti D, Solekhan A. Hubungan antara Status Gizi dengan Perkembangan Motorik Kasar Anak Balita di RSUD Tugurejo Semarang Tahun 2013. J Ilmu Keperawatan dan Kebidanan. 2013;33(4):1-8.

20. Prado EL, Dewey KG. Nutrition and Brain Development in Early Life. Nutr Rev [Internet]. $2014 \quad$ Apr;72(4):267-84. Available from: https://academic.oup.com/nutritionreviews/article-lookup/doi/10.1111/nure.12102

21. Lindawati. Faktor-Faktor yang Berhubungan dengan Perkembangan Motorik Anak Usia Pra Sekolah. J Heal Qual [Internet]. 2013 Nov 1 [cited 2020 May 19];4(1). Available https://www.poltekkesjakarta1.ac.id/file/dokumen/46JURNAL_LINDAWATI.pdf

22. Kasenda M, Sarimin S, Onibala F. Hubungan Status Gizi dengan Perkembangan Motorik Halus pada Anak Usia Prasekolah di TK Gmim Solafide Kelurahan Uner Kecamatan Kawangkoan Induk Kabupaten Minahasa. J Keperawatan UNSRAT. 2015;3(1):111221.

23. Jahari A, Saco-Pollitt C, Husaini M, Pollitt E. Effects of an Energy and Micronutrient Supplement on Motor Development and Motor Activity in Undernourished Children in Indonesia. Eur J Clin Nutr [Internet]. 2000 May 1;54(S2):S60-8. Available from: http://www.nature.com/articles/1601006

24. Watanabe K, Flores R, Fujiwara J, Tran LTH. Early Childhood Development Interventions and Cognitive Development of Young Children in Rural Vietnam. J Nutr [Internet]. $2005 \quad$ Aug 1;135(8):1918-25. Available from: https://academic.oup.com/jn/article/135/8/1918/4663909 